\title{
PENGARUH APLIKASI MEDAN ELEKTROMAGNET TERHADAP SIFAT FISIS AIR SERTA IMPLIKASINYA TERHADAP KECEPATAN PERTUMBUHAN TANAMAN
}

Oleh:

Fitri Purworini ${ }^{1}$, Avin Ainur Fitrianingsih ${ }^{2}$

\begin{abstract}
ABSTRAK: Ketersediaan air bersih yang berkualitas bagi manusia semakin terbatas. Tujuan dari penelitian ini mengaplikasi medan elektromagnet untuk memperbaiki kualitas air tersebut. Pada penelitian ini beberapa pipa telah dibuat yakni pipa toroida, pipa rodin dan pipa cadeceus yang kemudian dialiri air PDAM dan dihubungkan dengan medan elektromagnet. Air hasil olahan pipa-pipa tersebut kemudian diuji sifat fisis air yang meliputi uji $\mathrm{pH}$, uji suhu, dan uji konduktifitas listrik air. Air ini diamati pengaruhnya terhadap kecepatan pertumbuhan tanaman. Hasil penelitian menunjukkan nilai rata-rata $\mathrm{pH}$ dari air PDAM 6,84, air olahan pipa toroida 7,49 , pipa rodin 7,48 dan pipa cadeceus 7,42 . Nilai rata-rata suhu air PDAM adalah $25,18^{\circ} \mathrm{C}$, untukair olahan pipa toroida suhu inlet $27,08^{\circ} \mathrm{C}$ dan outlet $27,26^{\circ} \mathrm{C}$. Suhu inlet air olahan pipa cadeceus $27,74^{\circ} \mathrm{C}$ dan outlet $26,8^{\circ} \mathrm{C}$. Untuk suhu inlet air olahan pipa rodin $27,18^{\circ} \mathrm{C}$ dan suhu outlet $27,3^{\circ} \mathrm{C}$. Nilai rata-rata konduktivitas air olahan pipa toroida $3,24 \mu \mathrm{mho} / \mathrm{cm}$, pipa rodin $2,72 \mu \mathrm{mho} / \mathrm{cm}$, pipa cadeceus $3,61 \mu \mathrm{mho} / \mathrm{cm}$, dan untuk air PDAM nilai kondukivitas listriknya $1,86 \mu \mathrm{mho} / \mathrm{cm}$. Aplikasi medan elektromagnet tidak mempengaruhi kecepatan pertumbuhan tanaman cabai yang disiram menggunakan air olahan. Sedangkan pada tanaman terong, kecepatan pertumbuhan tanaman dipengaruhi oleh air olahan pipa toroida dengan rata-rata tinggi pertumbuhan tanaman $0,933 \mathrm{~cm} / \mathrm{minggu}$.
\end{abstract}

Kata kunci: Aplikasi medan elektromagnet; $\mathrm{pH}$; suhu; konduktifitas listrik; pertumbuhan tanaman.

\begin{abstract}
The availability of clean water quality for humans recently has been limited. The purpose of this study is applying an electromagnetic field to improve the water quality. In this research few pipes were contructed that were toroidal pipe, Rodin pipe and caduceus pipe. These were then drained by PDAM water and connected to an electromagnetic field. These processed water pipes were then tested its physical properties included $\mathrm{pH}$ test, test of temperature, and electrical conductivity. It was then observed its effects on plant growth rate.The study results showed that the average $\mathrm{pH}$ value of PDAM water, the processed toroid pipe water, the processed rodin pipe water and the processed cadeceus pipe water are 6.84; $7.49 ; 7.48$, and 7.42 respectively. The average temperatur of PDAM water is $25.18^{\circ}$ Celsius. In addition inlet and outlet temperature of the processed toroidal pipe water, the processed caduceus pipe water, the processed rodin pipe water were $27.26^{\circ}$ Celsius and $27.08^{\circ}$ Celsius; $27.74^{\circ}$ Celcius and $26.8^{\circ}$ Celsius; $27.18^{\circ}$ Celsius and $27.3^{\circ}$ Celsius respectively. The average electrical conductivity of PDAM water, the processed toroidal pipe water, the processed caduceus pipe water, the processed rodin pipe water were $1,86 \mu \mathrm{mho} / \mathrm{cm} ; 3.24 \mu \mathrm{mho} / \mathrm{cm}, 3.61$ $\mu \mathrm{mho} / \mathrm{cm}$ and $2,72 \mu \mathrm{mho} / \mathrm{cm}$ respectively. Application of electromagnetic fields did not affect the growth rate of pepper plants watered by using the processed waters. On the other hand the average height of eggplant growth were $0.933 \mathrm{~cm} /$ week under the processed toroid pipe water influence.
\end{abstract}

Keywords: Electromagnetic field applications; the physical properties of water; plant growth.

1 Mahasiswa Jurusan Fisika Fakultas Sains dan Teknologi, Universitas Islam Negeri Maulana Malik Ibrahim Malang. E-mail: purworinifitri@gmail.com

${ }^{2}$ Staf Pengajar Jurusan Fisika Fakultas Sains dan Teknologi, Universitas Islam Negeri Maulana Malik Ibrahim Malang. 


\section{PENDAHULUAN}

Tiada kehidupan tanpa air, dimana ada air disitulah ada kehidupan. Air telah menjadi sumber daya alami penting yang ada di bumi dan telah menjadi penting juga bagi keberadaan semua makhluk hidup. Hubungan yang dekat antara masyarakat dan air telahdi tandai dengan fakta bahwa hamper semua peradaban masa lampau dimulai dari sebuah sungai yang besar (1).

Secara medis juga telah dipaparkan bahwa tubuh manusia dalam kedinamisannya membutuhkan air yang bergerak dalam setiap rongga tubuhnya. Air itu akan mengontrol aliran darah dan membantu proses pencernaan makanan dalam lambung. Air juga dibutuhkan untuk mentransfer nutrisi dan zat lain dalam darah ke semua organ tubuh. Dengan air pula, tubuh dapat berada dalam batasan suhu normal dan mampu melepaskan toksin dalam tubuh (2).

Tapi karena aktifitas manusia yang kadang mengganggu proses alami air itulah yang justru merusak kandungan unsur-unsur yang ada pada air dan juga bahkan merusak alam yang merupakan produsen pembuat air bersih. Selain itu pada kondisi geologi tertentu dimana siklus air (air tanah) membutuhkan waktu ribuan tahun, sehingga bila pengambilan air tanah secara berlebihan, maka air akan habis (3).

Sehubungan dengan hal tersebut, perlunya upaya memperbaiki proses air yang secara alami. Karena kerusakan air akibat polusi yang dilakukan dengan sengaja ataupun tidak, untuk mendapatkan air yang layak konsumsi dengan menggunakan medan elektromagnet.

Adapun sifat-sifat air yang penting dapat digolongkan ke dalam tiga karakteristik, yaitu sifat fisik, kimiawi dan biologis (4).

a. Sifat Fisik

Air di dunia memiliki tiga macam bentuk, yakni padat sebagai es, cair sebagai air, dan gas sebagai uap air. Bentuk mana yang akan didapatkan, tergantung pada keadaan cuaca setempat. Sedangkan beberapa karakteristik fisik terpenting yang mempengaruhi kualitas air adalah bahan padat keseluruhan (baik yang terapung maupun yang terlarut), kekeruhan, warna, bau dan rasa, temperatur atau suhu.

b. Sifat Kimia

Air hujan maupun salju yang baru turun relatif murni. Begitu air mencapai permukaan bumi dan kemudian mengalir serta meresap ke dalam tanah, maka air melarutkan dan membawa bahan-bahan yang mudah larut dari temoat-tempat yang dilaluinya. Kandungan bahan-bahan kimia di dalam air berpengaruh terhadap kesesuaian penggunaan air. Secara umum karakteristik kimiawi air meliputi $\mathrm{pH}$, alkalinitas, kation dan anion terlarut, dan kesadahan.

c. Sifat Biologi

Air permukaan mengandung berbagai macam organisme hidup. Sedangkan air tanah lebih bersih karena proses penyaringan oleh akifer. Jenis-jenis organisme hidup yang mungkin terdapat dalam air meliputi makroskopik, mikroskopik, dan bakteri. Spesies 
organisme makroskopik dapat dilihat dengan mata telanjang, sedangkan organisme mikroskopik memerlukan alat bantu mikroskop untuk melihat perbedaan spesiesnya.

Penelitian ini menggunakan rancangan penelitian eksperimen laboratorik dengan pendekatan Pre Test dan Post TestControl menggunakan air PDAM sebagai sampel penelitian.Kemudian sampel dibagi menjadi empat kelompok besar (A, B, C, D), yang kemudian dibagi lagi menjadi sub sampel (A1, A2, A3, A4, A5; B1, B2, B3, B4, B5; C1, C2, C3, C4, C5; D1, D2, D3, D4, D5).Secara berurutan, sampel A adalah sampel netral air PDAM yang tidakmengalami perlakuan. Sampel B adalah sampel yang diberi perlakuanvariasi medan elektromagnet dari koil Rodin. Sampel C adalah sampel yang diberi perlakuan variasi medan elektromagnet dari koil toroida. Sampel D adalah sampel yang diberi perlakuan variasi medan elektromagnet dari koil Cadeceus. Masing-masing sampel kemudian diukur karakteristik fisisnya ( $\mathrm{pH}$, suhu, dan konduktivitas listrik). Kemudian masing-masing sampel diaplikasikanpada tanaman dan diamati pengaruhnya terhadap pertumbuhan tanaman.

Untuk pengambilan data tanaman, langakah awal yang dilakukanmenyediakan 8 buah pot tanaman, 4 buah pot untuk tanaman cabai dan 4 buah pot lainnya untuk tanaman terong. 2 pot digunakan untuk tanaman yang disiram menggunakan air PDAM, 2 pot untuk tanaman yang disiram menggunakan air olahan koil Rodin, 2 pot untuk tanaman yang disiram menggunakan air olahan koil Toronoida, dan 2 pot lainnya untuk tanaman yang disiram menggunakan air olahan koil Cadeceus. Untuk tanah yang akan digunakan pada setiap pot, ditimbang agar beratnya sama dengan pot satu dengan yang lain.Dalam setiap pot diisi 9-10 biji benih dan setiap pot nantinya akan diukur 5-7 biji benih. Pengukuran tanaman hanya dilakukan untuk tinggi batang pada tanaman.

Data hasil penelitian dari masing-masing kelompok diukur distribusinya dan apabila terdistribusi secara normal kemudian dilakukan analisis parametrik uji ANOVA menggunakan perangkat lunak MATLAB. Uji untuk melihat perbedaan dari masingmasing kelompok perlakuan dilakukan dengan uji variant dan untuk melihat signifikansi uji ANOVA menggunakan uji multicompare. Selain menggunakan uji ANOVA dengan MATLAB juga menggunakan uji ANOVA menggunakan SPSS dan menggunakan uji lanjut dengan uji Duncan.

\section{HASIL DAN PEMBAHASAN}

Dari hasil penelitian aplikasi medan elektromagnet, diperoleh hasil dari uji sifat fisis air sebagai berikut:

Uji pH yang dilakukan dalam penelitian ini dilakukan 5 kali pengulangan pada masing-masing sample dan pengujian $\mathrm{pH}$ menggunakan $\mathrm{pH}$ meter digital dengan inframerah. Gambar 1 menunjukkan hasil pengujian PH.

Gambar grafik batang uji $\mathrm{pH}$ di atas memberikan informasi bahwa air olahan memiliki nilai $\mathrm{pH}$ yang lebih tinggi (atau mendekati sifat kebasaan dalam air) dibandingkan dengan air PDAM (sample yang terkontrol). Dapat dilihat juga pada grafik diatas bahwa air olahan pipa torida memiliki nilai $\mathrm{pH}$ yang lebih tinggi dibandingkan dengan air olahan pipa rodin dan cadeceus. 
Untuk penghitungan statistik dengan lebih akurat pada $\mathrm{pH}$ air, maka dilakukan uji ANOVA menggunakan SPSS. Selanjutnya dilakukan uji Duncan sebagai uji lanjut untuk menentukan air olahan yang lebih signifikan mempengaruhi $\mathrm{pH}$ air. Berikut adalah tabel ANOVA dan uji Duncan:

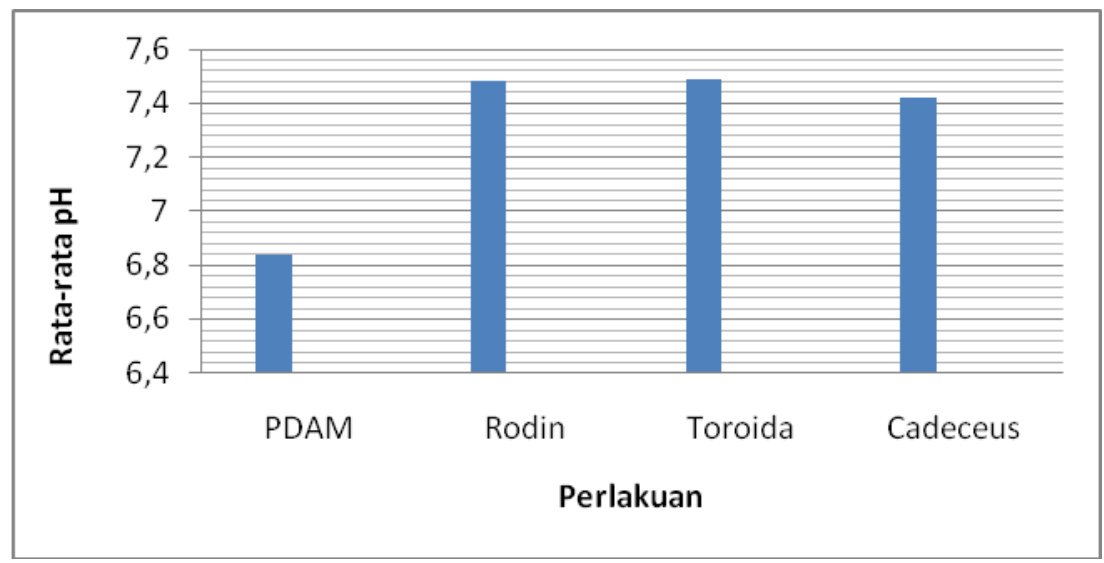

Gambar 1. Grafik uji rata-rata $\mathrm{pH}$

Tabel 1. Uji ANOVA menggunakan SPSS untuk pengaruh aplikasi medan elektromagnet pada $\mathrm{pH}$ air

\begin{tabular}{cccccc}
\hline & $\begin{array}{c}\text { Sum of } \\
\text { Squares }\end{array}$ & df & $\begin{array}{c}\text { Mean } \\
\text { Square }\end{array}$ & F & Sig. \\
\hline Between & 1.490 & 3 & .497 & 30.374 & .000 \\
$\begin{array}{c}\text { Groups } \\
\text { Within Groups } \\
\text { Total }\end{array}$ & .262 & 16 & .016 & & \\
\hline
\end{tabular}

Tabel 2. Uji Duncan menggunakan SPSS untuk pengaruh aplikasi medan elektromagnet pada $\mathrm{pH}$ air

\begin{tabular}{ccccc}
\hline & $\mathrm{N}$ & \multicolumn{2}{c}{ Subset for alpha $=.05$} & \\
\cline { 2 - 4 } air & 1 & 2 & 1 & Ket: 1.00 air PDAM \\
\hline 1.00 & 5 & 6.8400 & & 2.00 air Rodin \\
4.00 & 5 & & 7.4200 & \\
2.00 & 5 & & 7.4820 & \\
3.00 & 5 & & 7.4980 & \\
Sig. & & 1.000 & .375 & \\
\hline
\end{tabular}

Dari tabel ANOVA diatas, dapat dilihat nilai signifikansi $\mathrm{pH}, 000$. Sehingga, dapat dikatan bahwa aplikasi medan elektromagnet mempengaruhi $\mathrm{pH}$ air olahan. Selanjutnya pada uji Duncan menunjukkan bahwa perlakuan 3,00 merupakan perlakuan yang paling signifikan dibandingkan perlakuan yang lain. Perlakuan 3,00 merupakan air yang dialirkan melalui pipa toroida. Terkait dengan kuat medan magnet, pada pipa toroida menghasilkan kuat medan magnet 18,97 mT. Medan magnet pada pipa toroida merupakan yang paling besar bila dibandingkan dengan pipa yang lain. Besarnya kuat medan tersebut dapat mempengaruhi $\mathrm{pH}$ air olahan sehingga dapat memperbaiki kualitas air.

Data uji suhu pada penelitian ini dapat dilihat pada gambar 2 dibawah ini. 


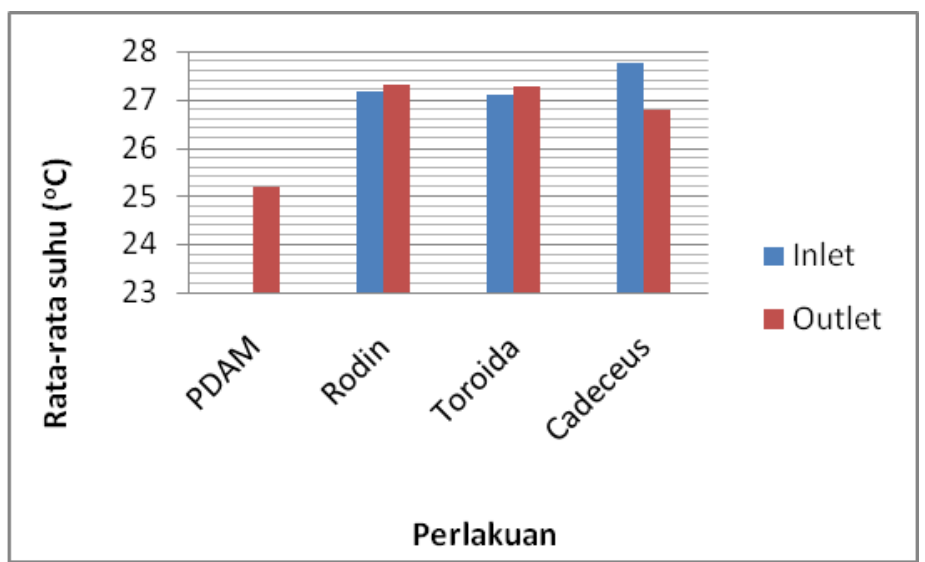

Gambar 2.Grafik uji rata-rata suhu

Selanjutnya pengujian suhu air secara statistika menggunakan uji ANOVA pada MATLAB ditunjukkan pada tabel berikut:

Tabel 3. Data uji ANOVA pengaruh aplikasi medan elektromagnet pada suhu air

\begin{tabular}{cccccc}
\hline Source & 'SS' & 'df' & 'MS' & 'F' & 'Prob>F' \\
\hline Columns & {$[14.026]$} & {$[3]$} & {$[4.67533]$} & {$[4.91]$} & {$[0.0132]$} \\
Error & {$[15.244]$} & {$[16]$} & {$[0.95275]$} & {[]} & {[]} \\
Total & {$[29.27]$} & {$[19]$} & {[]} & {[]} & {[]} \\
\hline
\end{tabular}
berikut:

Uji signifikansi pada suhu air, uji ANOVA dengan SPSS ditunjukkan pada tabel 4

Tabel 4. Uji signifikansi pengaruh aplikasi medan elektromagnet pada suhu air pada MATLAB

\begin{tabular}{cccccc}
\hline & $\begin{array}{c}\text { Sum of } \\
\text { Squares }\end{array}$ & df & $\begin{array}{c}\text { Mean } \\
\text { Square }\end{array}$ & F & Sig. \\
\hline Between & .081 & 1 & .081 & .107 & .752 \\
$\begin{array}{c}\text { Groups } \\
\text { Within Groups }\end{array}$ & 6.060 & 8 & .758 & & \\
$\quad$ Total & 6.141 & 9 & & & \\
\hline
\end{tabular}

Dari data uji ANOVA suhu air diatas diperoleh nilai probabilitas 'Prob $>F$ ' 0,0132. Nilai tersebut lebih kecil dari standar statistika yaitu 0,05 , sehingga dapat dinyatakan bahwa $\mathrm{H}_{0}$ ditolak dan $\mathrm{H}_{1}$ diterima. Ini menunjukkan bahwa ada pengaruh medan elektromagnet terhadap suhu air olahan. Sedangkan untuk uji signifikansi pada SPSS menunjukkan hasil bahwa kurangnya signifikan aplikasi medan elektromagnet terhadap suhu air olahan, meskipun pada tabel uji ANOVA pada MATLAB menunjukkan adanya pengaruh terhadap suhu. Hal itu ditunjukkan dengan adanya nilai signifikan ,752 pada tabel signifikansi. Nilai tersebut jauh lebih besar dari standar statistika 0,05. Sehingga dapat dinyatakan bahwa aplikasi medan elektromagnet mempengaruhi suhu air olahan meskipun kurang signifikan.

Dari kedua tabel diatas, medan elektromagnet menunjukkan hasil yang kurang signifikan. Namun, pada gambar 2 menunjukkan bahwa air olahan cadeceus lebih 
mempengaruhi suhu air yang semula pada inlet suhu air lebih panas, namun pada outlet suhu air menjadi lebih dingin. Kuat medan magnet pada pipa cadeceus 18,76 mT. Dengan kuat medan yang dihasilkan oleh pipa cedeceus tersebut, dapat mengubah air menjadi lebih dingin seperti yang dilakukan oleh alam. Dapat dikatakan, pada suhu air tidak dimungkinkan menggunakan kuat medan magnet yang lebih tinggi seperti pada pipa toroida maupun kuat medan magnet yang lebih rendah seperti pada pipa rodin 18,20 mT dan sisi pipa rodin yang lain $18,68 \mathrm{mT}$.

Data uji konduktifitas listrik atau daya hantar listrik (DHL) dapat dilihat pada gambar 3.

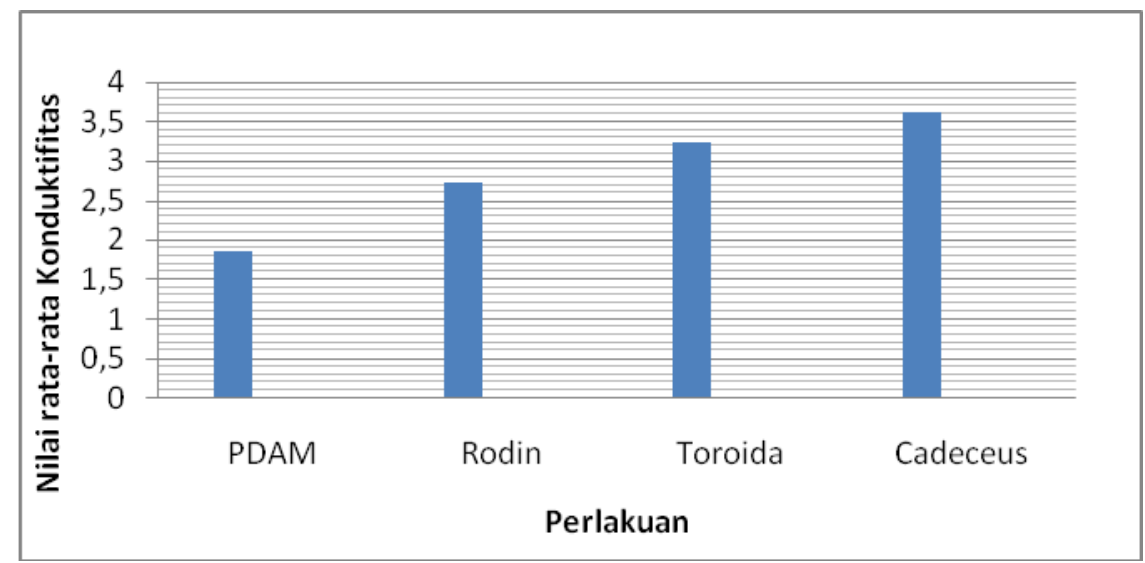

Gambar 3. Grafik uji rata-rata konduktifitas listrik air olahan

Tabel 5. Data uji ANOVA pengaruh aplikasi medan elektromagnet pada konduktifitas listrik air

\begin{tabular}{cccccc}
\hline Source & 'SS' & 'df' & 'MS' & 'F' & 'Prob>F' \\
\hline Columns & {$[10.2467]$} & {$[3]$} & {$[3.41555]$} & {$[10.91)$} & {$[0.0004]$} \\
Error & {$[5.0083]$} & {$[16]$} & {$[0.31302]$} & {[]} & {[]} \\
Total & {$[15.255]$} & {$[19]$} & {[]} & {[]} & {[]} \\
\hline
\end{tabular}

Tabel 6. Data uji Duncan pengaruh aplikasi medan elektromagnet pada konduktifitaslistrik air

\begin{tabular}{|c|c|c|c|c|c|}
\hline \multirow{2}{*}{ Air } & $\mathrm{N}$ & \multicolumn{3}{|c|}{ Subset for alpha $=.05$} & \multirow{3}{*}{$\begin{array}{c}\text { Ket: } 1.00 \text { air PDAM } \\
2.00 \text { air Rodin }\end{array}$} \\
\hline & 1 & 2 & 3 & 4 & \\
\hline 1.00 & 5 & 1.8680 & & & \\
\hline 2.00 & 5 & & 2.7260 & & 3.00 air Toroida \\
\hline 3.00 & 5 & & 3.2400 & 3.2400 & 4.00 air Cadeceus \\
\hline 4.00 & 5 & & & 3.8160 & \\
\hline Sig. & & 1.000 & .166 & .123 & \\
\hline
\end{tabular}

Dari data uji ANOVA konduktifitas air pada tabel 5, dapat dilihat bahwa nilai probabilitas 0,0004. Nilai 'Prob $>$ F' 0,0004 tersebut lebih kecil dari nilai standar statistika 0,05. Ini berarti $\mathrm{H}_{0}$ ditolak dan $\mathrm{H}_{1}$ diterima. $\mathrm{H}_{1}$ menyatakan adanya pengaruh aplikasi medan elektromagnet terhadap konduktifitas listrik air olahan.

Selanjutnya, uji signifikansi menggunakan uji Duncan pada SPSS ditujukkan pada tabel 6. Dari tabel uji Duncan pada tabel 6 dapat menunjukkan bahwa perlakuan 4,00 
merupakan perlakuan yang paling signifikan dibandingkan perlakuan yang lain. Perlakuan 4,00 merupakan air yang dialirkan melalui pipa cadeceus. Kuat medan magnet pada pipa cadeceus 18,76 mT. Dengan kuat medan yang dihasilkan oleh pipa cedeceus tersebut, dapat mengubah konduktifitas listrik air menjadi lebih besar dibandingkan dengan pipa yang lain. Dapat dikatakan, pada konduktifitas listrik air tidak dimungkinkan menggunakan kuat medan magnet yang lebih tinggi seperti pada pipa toroida maupun kuat medan magnet yang lebih rendah seperti pada pipa rodin $18,20 \mathrm{mT}$ dan sisi pipa rodin yang lain 18,68 mT.

Kuat medan magnet pada pipa cadeceus dapat memutuskan ikatan polar pada air saat melewati pipa yang diberi medan magnet. Pemberian medan magnet tersebut diharapkan mampu merekonstruksi ikatan polar pada air sehingga mampu meningkatkan konduktifitas listrik pada air yang telah diaplikasikan dengan medan magnet. Dapat dikatakan juga bahwa air olahan pipa cadeceus memiliki suatu ion di dalam larutan yang mudah bergerak sehingga mempunyai nilai DHL yang besar dan dapat dikatakan juga bahwa mineral di dalam airnya lebih banyak daripada air olahan lain karena memiliki nilai DHL yang lebih tinggi.

Pengaplikasian medan elektromagnet tidak hanya pada sifat fisis air saja, namun juga diaplikasikan pada tanaman untuk menganalisis bagaimana pengaruhnya terhadap kecepatan pertumbuhan tanaman. Tanaman yang digunakan pada penelitian ini adalah tanaman terong dan cabai. Benih-benih tanaman tersebut ditanam pada media pot yang berjumlah delapan. Empat pot berisi benih terong dan empat pot lainnya berisi benih cabai. Jumlah tanaman disesuaikan dengan jumlah sample air olahan. Hal ini dilakukan agar mempermudah pengambilan data pertumbuhan tanaman. Setiap pot diisi benih masing masing sebanyak 9-11 buah benih yang nantinya hanya 5 tanaman yang akan diamati pertumbuhannya. Pada setiap pot diberi label nama air olahan yang akan disiramkan pada tanaman seperti air PDAM, air pipa rodin, air pipa toroida, dan air pipa cadeceus. Penyiraman dilakukan setiap pagi hari dan pengambilan data dilakukan selama 9 minggu. Pengukuran dilakukan setiap seminggu sekali pada hari ketiga. Data tanaman cabai dan terong disajikan pada gambar 4 dan 5 batang dibawah ini:

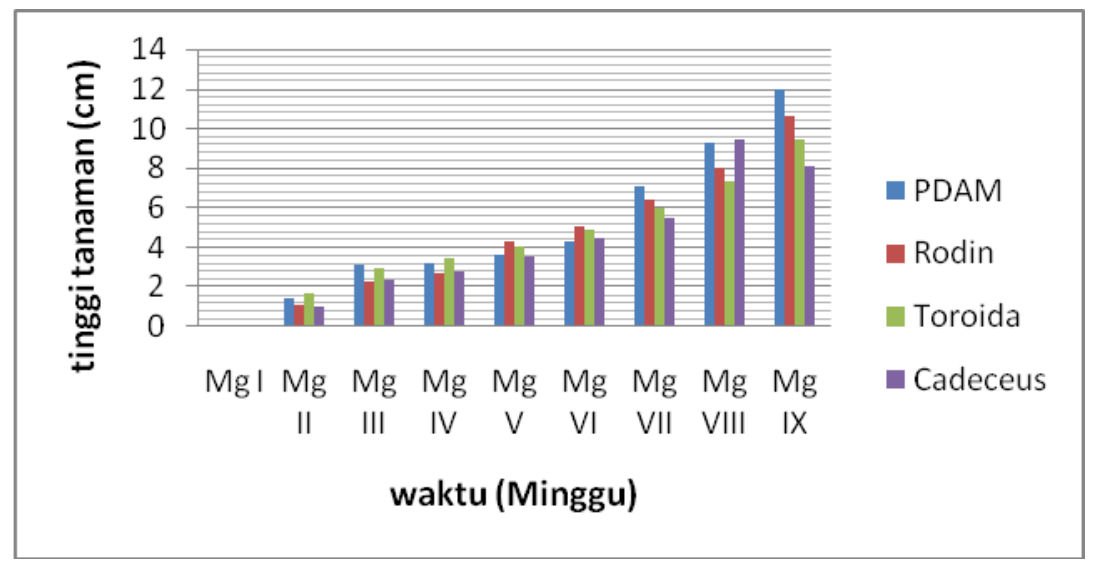

Gambar 4. Grafik batang pertumbuhan tanaman cabai 


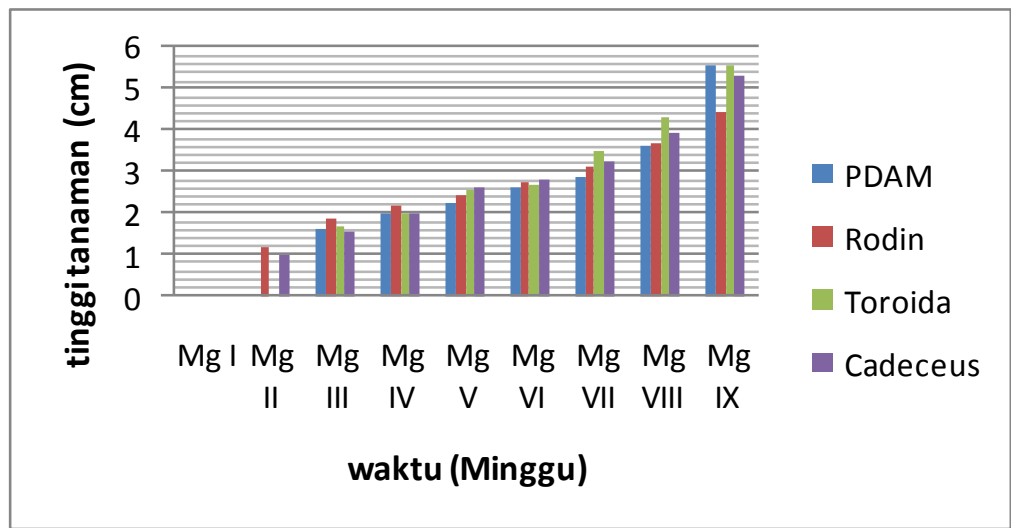

Gambar 5. Grafik batang pertumbuhan tanaman terong

Dari data-data penelitian tersebut juga diuji signifikansi air yang lebih berpengaruh terhadap tanaman cabai menggunakan uji Duncan pada SPSS.

Tabel 7. Uji Duncan pada tanaman cabai

\begin{tabular}{rcccc}
\hline \multirow{2}{*}{ Air } & $\mathrm{N}$ & \multicolumn{3}{c}{ Subset } \\
\cline { 2 - 5 } & 1 & 2 & 3 & 1 \\
\hline 4.0 & 45 & 3.80 & & \\
3.0 & 45 & & 4.41 & \\
2.0 & 45 & & 4.43 & \\
1.0 & 45 & & & 4.76 \\
Sig. & & 1.000 & .876 & 1.000 \\
\hline
\end{tabular}

Ket: 1.00 air PDAM

2.00 air Rodin

3.00 air Toroida

4.00 air Cadeceus

Dari tabel uji Duncan tersebut terlihat perlakuan 1,00 merupakan perlakuan yang paling signifikan dibandingkan dengan perlakuan lain. Perlakuan 1,00 merupakan air terkontrol yakni air yang tidak mengalami perlakuan apapun (air PDAM). Pada gambar 4.8 grafik tanaman cabai dapat kita lihat bahwa air PDAM yang mengalami kecepatan pertumbuhan tanaman yang paling cepat. Sedangkan untuk air olahan lain mengalami kecepatan pertumbuhan setelah air PDAM.

Untuk tanaman cabai, aplikasi medan elektromagnet tidak mempengaruhi percepatan pertumbuhan tanaman. Kuat medan magnet yang dihasilkan oleh pipa toroida, pipa rodin dan pipa cadeceus tidak memberikan efek yang dapat mempengaruhi pertumbuhan terhadap tanaman cabai.

Dari data-data penelitian pertumbuhan tanaman terong, kemudian diuji signifikansi air yang lebih berpengaruh terhadap tanaman terong menggunakan uji Duncan pada SPSS.

Tabel 8 Uji Duncan pada tanaman terong

\begin{tabular}{cccr}
\hline \multirow{2}{*}{ Air } & $\mathrm{N}$ & \multicolumn{2}{c}{ Subset } \\
\cline { 2 - 4 } & 1 & 2 & 1 \\
\hline \multirow{2}{*}{1.00} & 45 & 2.2 & \\
& & 800 & \\
2.00 & 45 & 2.3 & 2.3 \\
& & 311 & 311 \\
4.00 & 45 & 2.4 & 2.4 \\
& & 222 & 222 \\
3.00 & 45 & & 2.4
\end{tabular}

Ket: 1.00 air PDAM

2.00 air Rodin

3.00 air Toroida

4.00 air Cadeceus 


\begin{tabular}{crr} 
& & 711 \\
Sig. & .09 & .10 \\
& 5 & 0 \\
\hline
\end{tabular}

Dari tabel 8 uji Duncan tersebut terlihat perlakuan 3,00 merupakan perlakuan yang paling signifikan dibandingkan dengan perlakuan lain. Perlakuan 3,00 merupakan air toroida. Pada gambar 4.9 grafik tanaman terong dapat kita lihat bahwa air toroida yang mengalami kecepatan pertumbuhan tanaman yang paling cepat dibandingkan air olahan lain.

Untuk tanaman terong, aplikasi medan elektromagnet mempengaruhi percepatan pertumbuhan tanaman dengan air olahan pipa toroida. Kuat medan magnet yang dihasilkan oleh pipa toroida dapat mempengaruhi pertumbuhan terhadap tanaman terong. Dengan air yang dihasilkan dari pipa toroida juga dapat memperbaiki kualitas air lebih baik. Dengan kualitas yang lebih baik pula, bila diberikan untuk tanaman, maka tanaman tersebut juga akan tumbuh lebih cepat.

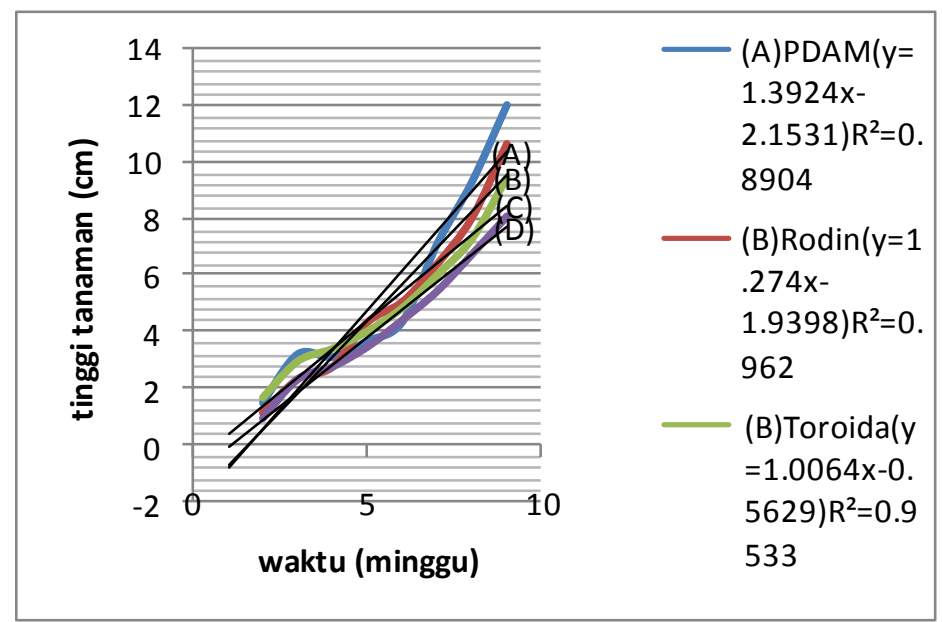

Gambar 6. Grafik pertumbuhan tanaman cabai

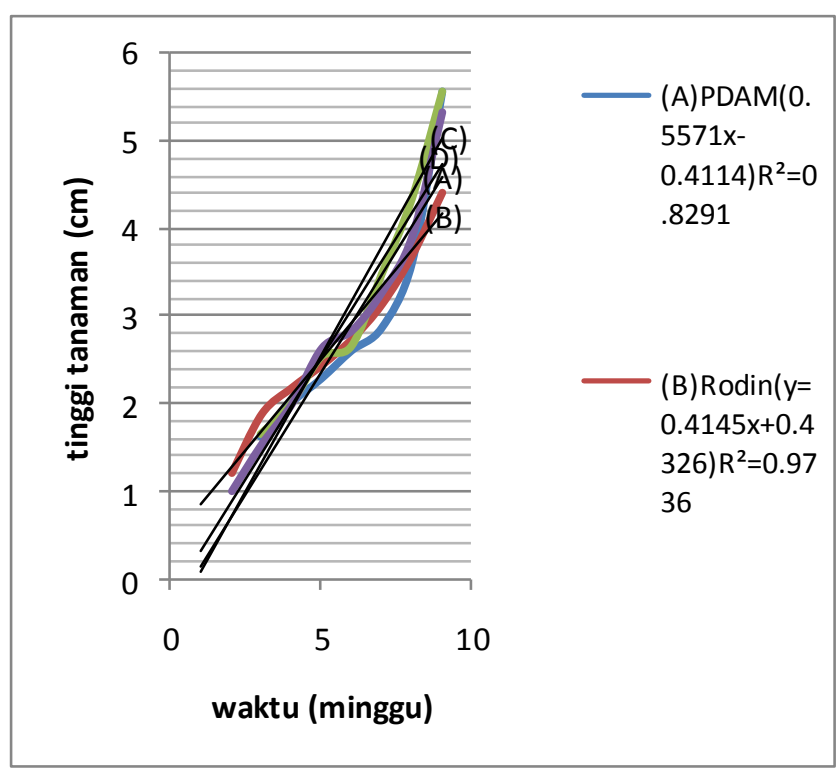

Gambar 7. Grafik pertumbuhan tanaman terong 


\section{KESIMPULAN}

1. Aplikasi medan elektromagnet pada air olahan pipa toroida lebih mempengaruhi sifat fisis air yaitu dengan nilai rata-rata $\mathrm{pH} 7,49$. Pada sifat fisis air yang meliputi suhu dan konduktifitas listrik dengan rata-rata suhu inlet $27,74^{\circ} \mathrm{C}$ dan outlet $26,8^{\circ} \mathrm{Cserta}$ nilai rata-rata konduktifitas listrik $3,61 \mu \mathrm{mho} / \mathrm{cm}$, air olahan pipa cadeceus lebih berpengaruh terhadap air olahan.

2. Aplikasi medan elektromagnet tidak mempengaruhi kecepatan pertumbuhan tanaman cabai yang disiram menggunakan air olahan. Sedangkan pada tanaman terong, kecepatan pertumbuhan tanaman dipengaruhi oleh air olahan pipa toroida dengan ratarata tinggi pertumbuhan tanaman $0,933 \mathrm{~cm} / \mathrm{minggu}$.

\section{DAFTAR PUSTAKA}

(1) Takahide, Santo. Handbook of Water Treatment. Tokyo: Japan; 1999.

(2) Jazuli, Ahzami Samiun. Kehidupan Dalam Pandangan Al-Qur'an. Jakarta: Gema Insani; . 2006.

(3) Kadoatie, R. J. dan Roesman S. Tata Ruang Air. Yogyakarta: ANDI; 2010.

(4) Supirin. Pelestarian Sumber Daya Tanan dan Air. Yogyakarta: ANDI; . 2004. 